\title{
metios agt
}

\section{Recent Research in Genetics and Genomics 2019; 1(1): 1-7}

\section{Original article:}

Inhibition of Human Breast cancer cells proliferation by Graviola crude extract 'Graviola anticancer activity"

\author{
Razan M.H Mohammed, Magda M. Noshy, Hanan R.H Mohamed* \\ Zoology Department; Faculty of science Cairo University; Giza, Egypt
}

Correspondence to: hananesresm@yahoo.com doi:10.21608/RRGG.2019.50222. Received: 01

September 2019; Accepted: 18 September; Published: 01 November 2019

\begin{abstract}
Rapid increases in cancer and human death cases, as well as the fatal side effects of chemotherapy, have forced the seek new safer anti-cancer drugs. Therefore, the current study was conducted to study the effect of Graviola leaf extract on the proliferation of human breast cancer (MCF-7) cell lines. MCF-7 cells were cultured and a Neutral red uptake assay was done to estimate the effect of Graviola extract on MCF-7 cells' proliferation. Treatment with different concentrations of Graviola leaf extract inhibited the proliferation of MCF-7 cells in a concentration-dependent manner. Conclusion: Graviola leaf extract has a promising inhibitory effect against the proliferation of MCF-7 cells.
\end{abstract}

Keywords: MCF-7 cells; Graviola; NR assay; proliferation; cytotoxicity

\section{Introduction}

Cancer is a large group of diseases with the common feature of uncontrolled growth of cells; these cells have the ability of invasion and spreading to other part and organs of the body. All cells are sensitive but epithelial cells are most likely to change (International Agency for Research on Cancer, 2018).

Breast cancer is characterized by uncontrolled growth of abnormal cells in the milk producing glands of the breast or in the passages (ducts) that transport milk to the nipples (Roche, 2016) The American Cancer Society estimated nearly 270000 new cases and about 40000 deaths due to breast cancer in women in the United States in 2010 alone (Reuben et al., 2012).

Commercially, there are many drugs used to treat cancer but unfortunately, almost all of 
these drugs threaten human life with their side effects. The motivation for increased research interest in estimating the anticancer potential of natural extracts and their derivatives is driven by the fact that most natural products have less toxicity and higher safety compared to existing chemotherapy drugs used (Greenwell and Rahman, 2015).

Nowadays more than 100 annonaceous Acetogenins are commonly used as a family of natural products with antitumor activities such as those derived from roots, leaves, barks, fruits and seeds of Graviola have been widely used in alternative medicine for many purposes. In the Peruvian Andes for example, the Graviola leaves are used to combat parasites and treat diabetes. In the Brazilian Amazon, the leaves used to treat liver problems and the leave-extracted oil believed to help with rheumatism, neuralgia and arthritis. In the Eastern Andes and Jamaica, the juice of Graviola was used to stop diarrhea, muscle relaxant and lower the intestinal acidity (Adeyemi et al., 2008; Pai et al., 2016; Zamudio-Cuevas et al., 2014).

Graviola also exhibited anti-cancer properties against many cancer cell lines: prostate adenocarcinoma, lung carcinoma, pancreatic carcinoma, colon adenocarcinoma, liver cancer and human lymphoma cell lines by reducing cell viability and morphology changes leading to loss of mitochondrial membrane potential and cell cycle arrest especially at G0/G1 phase stimulated apoptosis (Torres et al., 2012; Pieme et al., 2014; Syed Najmuddin et al., 2016). However, the effect of Graviola on the viability of human breast cell lines (MCF-7) cell lines has not been well investigated; therefore, the current study was carried out to study the influence of Graviola leaf extract on MCF-7 cells proliferation.

\section{Materials and methods}

\subsection{Chemicals:}

\subsubsection{Graviola crude extract}

Graviola leave crude extract was manufactured in USA for Superior lab Inc. (San Diego CA 92129) and purchased from Societe Francaise Egyptienne la Belle Company located at 22, Mahmoud Hassan Street, Heliopolis Square - Cairo - Egypt with serial number 850569006056 .

\subsection{Cell lines}

Epithelial-like Human Breast cancer (MCF-7) cell line derived from mammary gland of the female human breast tissue was purchased from the Research Park in Faculty of Agriculture-Cairo University, Giza Egypt.

\section{3 ethical considerations}

All experimentations conducted in the current study were approved by the Institutional Animal Care and Use Committee at the Faculty of Science, Cairo University (CUIACUC) Egypt with the approval number (CUIFCl28\18).

\subsection{Estimation of cell viability using Neutral red uptake assay \\ Neutral red uptake assay was done in the Cell culture lab, CURP, Faculty of agriculture,}


Cairo University according to the protocol described by Repetto and his colleagues, (2008).

\subsubsection{Cells seeding}

1. MCF-7 cells incubated in the medium were decanted and rinse by gentle agitation in PBS-without $\mathrm{Ca}^{2+}$ and $\mathrm{Mg}^{2+}$ at $37^{0} \mathrm{C}$ to removes any remaining serum that might inhibit the action of the trypsin.

2. Added $2 \mathrm{ml}$ of trypsin-EDTA solution at $37^{0} \mathrm{C}$ to the monolayer then agitated gently, to remove excess trypsin-EDTA solution and incubated the cells at $37^{\circ} \mathrm{C}$ for 2-5 min.

3. The flask was lightly pressed to separate the cells and complete culture medium was added. Gently crush to ensure that a singlecell suspension is obtained.

4. Cultured MCF-7 cells were counted using a hemocytometer to ensure that cells' viability is $\geq 95 \%$.

5. The cells were diluted with complete medium to prepare a uniform cell suspension of an adequate cell density.

6. $200 \mu \mathrm{l}$ of the cell suspension dispensed into the wells of the plate and incubated overnight at $37^{\circ} \mathrm{C}$ under $5 \% \mathrm{CO}_{2}$.

\subsubsection{Cells treatment}

1. Correct cells' growth was checked using a phase Contrast Inverted microscope.

2. The culture medium was decanted from the plates.

3. A $200 \mu \mathrm{l}$ of treatment medium without chemicals was added to the wells of columns 1, 2 and 12 and representing negative control.

4. Added $200 \mu \mathrm{l}$ of treatment medium containing an equivalent amount of solvent to the column 3 representing positive control.

5. A $200 \mathrm{ml}$ of the treatment media containing Graviola crude extract dissolved in DMSO in increasing concentrations $(20,40,80$ and $120 \mu \mathrm{g} / \mathrm{ml}$ ) to the wells of columns C4-C11 representing Graviola treatment. Each concentration was conducted in four replicates.

6. Incubated the plate for $24 \mathrm{~h}$ at $37^{\circ} \mathrm{C}$ under $5 \% \mathrm{CO}_{2}$.

\subsubsection{Neutral red uptake}

1. The treatment medium containing the Graviola extract was removed from the cultured cells.

2. A $100 \mu \mathrm{l}$ of neutral red was added to each well of the plate and incubated for $2 \mathrm{~h}$. at at $37^{\circ} \mathrm{C}$ under $5 \% \mathrm{CO}_{2}$ to allow the uptake of neutral red.

3. After incubation, the cells were washed with $150 \mu 1$ PBS per well by covering or immersing the plate in PBS and removing the washing solution by gentle tapping.

4. A $150 \mu \mathrm{l}$ neutral red de-stain solution was added per well and shacked in the shaker for at least $10 \mathrm{~min}$ until the neutral red has extracted from the cells and has formed a homogeneous solution.

5. Cells were imaged and analyzed. 


\section{Results}

\subsection{Cells' viability}

As shown in Fig. 1 the proliferation of Human breast cancer (MCF-7) cells was severely inhibited after treatment with Graviola different concentrations $(20,40,80$ or 120 $\mu \mathrm{g} / \mathrm{ml}$ ) in a concentration dependent manner as the number of viable MCF-7 cells decreased
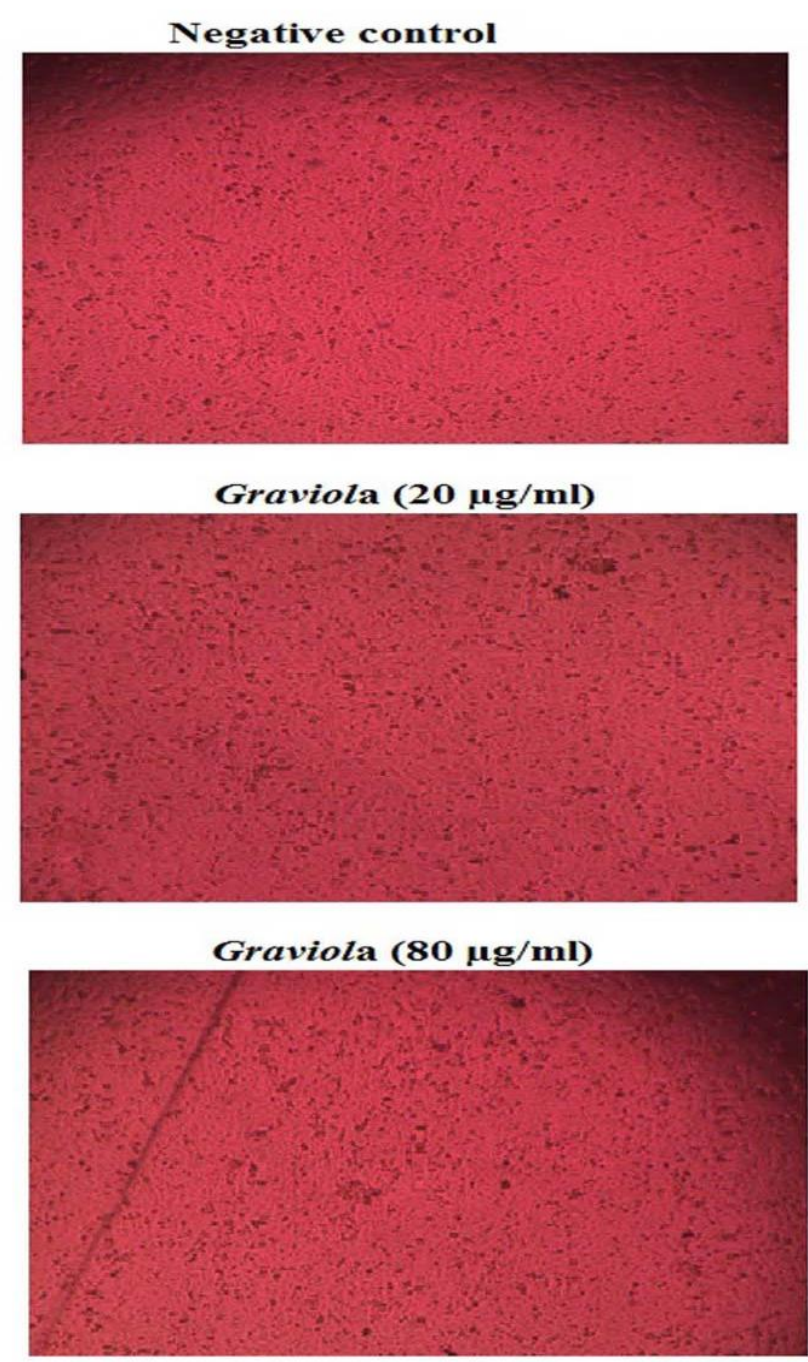

Fig. 1: Viability of Human breast cancer (MCF-7) cells treated with different concentrations of Graviola crude extract compared to the positive (solvent treated) and negative controls

\section{Discussion}

With high increases in the incidence of cancer, more than 7 million people will die in 2020 from cancer globally and the number of with increasing Graviola concentration compared with cells treated with culture medium only (negative control). On the other hand, the proliferation of MCF-7 cells treated with culture medium containing DMSO (positive control) was unchanged and remained in the negative control level.
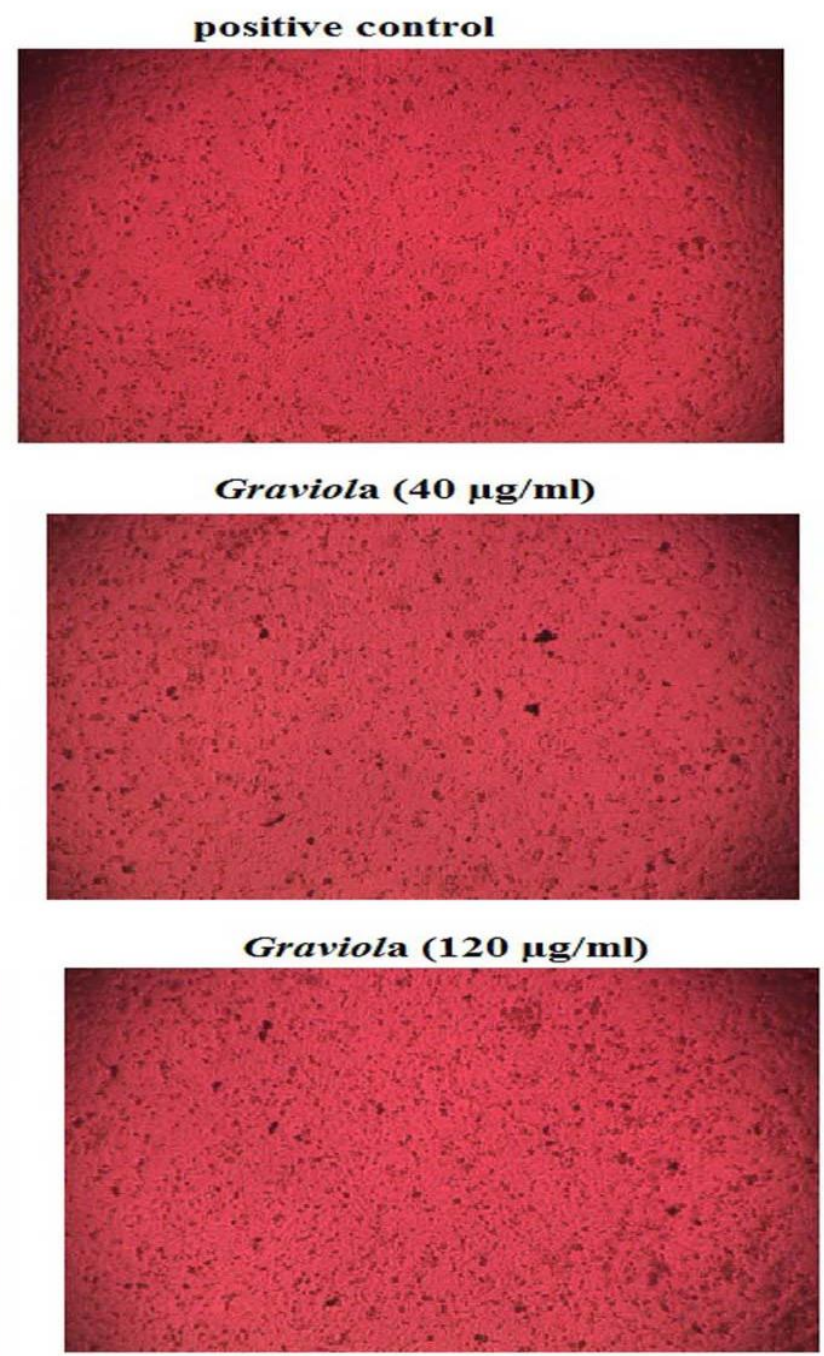
There are several types of cancer treatment including surgery, radiation and chemotherapy. Despite the availability of many chemotherapeutic drugs, they cause many disorders and toxicity to normal human cells such as neurotoxicity, hepatotoxicity,

Many natural extracts and their derivatives have shown promising anti-cancer efficacy against many cancers including breast, lung, prostate, liver etc. without any effect on normal cells either in vitro or in vivo (Ioannis et al., 2015). Therefore, this study was conducted to study the effect of Graviola crude extract on human breast cancer (MF-7) cell proliferation.

Results of current study explored the antproliferative effect of Graviola crude extract, which was manifested by the concentration dependent decreases observed in the number of viable MCF-7 cells treated with Graviola different concentrations in consistence with previous studies that showed that Graviola extract inhibited the proliferation of various cancer cell lines including leukemia, skin, colon and lung cancer cells (Ezirim et al., 2013; Moghadamtousi et al., 2014).

The exact mechanism of the antiproliferative effect of Graviola leaf extract has not been determined. However, the extract of Graviola leaf has been shown to induce cell cycle arrest at G1 phase and apoptosis through different pathways including mitochondrialmediated pathway in colon and lung cancer and activating caspase 3 pathway in myelogenous cardiotoxicity, etc., that threatens human life. Therefore, there is a recent trend in the search for new anti-cancer drugs that have no or less toxic effects (Elad et al., 2010; Greenwell and Rahman, 2015).

leukemia K562 cell (Ezirim et al., 2013; Moghadamtousi et al., 2014).

In conclusion: Graviola leaf extract has shown promising cytotoxic activity against human breast MCF-7 cells as manifested by the observed concentration dependent inhibition of MCF-7 cells' proliferation.

\section{Acknowledgement}

All thanks and appreciation to the Department of Zoology, Faculty of Science, Cairo University for providing us with the necessary equipment for the experimental part of this study

\section{Author contributions}

All authors designed the present study. H.M and R.M executed the experimental work, performed data analyses and wrote the manuscript. HM revised the final manuscript.

\section{Conflict of interest}

All authors declared no conflict of interest.

\section{References}

Adeyemi, DO, Komolafe, OA, Adewole, SO, Obuotor, EM, Adenowo, TK. (2008) Effects of Annona muricata (Linn) on the morphology of pancreatic islet cells of experimentally-induced diabetic Wistar rats. Internet J. Altern. Med. 5, 2. 
Aghabarari, M, Ahamadi, F, Mohammadi, E, Hajizadeh, E, Farahania V. (2005) Physical, emotional and social dimension of quality of life among breast cancer women under chemotherapy. Iranian Journal of Nursing Research. 3: 55-65.

Elad, S, Zadik, Y, Hewson, I, Hovan, A, Correa, ME, Logan, R, Elting, LS, Spijkervet, FK, Brennan, MT. (2010). "A systematic review of viral infections associated with oral involvement in cancer patients: a spotlight on Herpesviridea". Supportive Care in Cancer. 18 (8): 9931006.

Ezirim, A, Okachi, V, James, A, Adebeshi, O, Ogunnowo, S, Odeghe, O. (2013) Induction of apoptosis in myelogenous leukemic k562 cells by ethanolic leaf extract of Annona muricata. Indian J. Drug Dis. 2:142-151.

Greenwell, $M$ and Rahman, P.K.S.M. (2015). Medicinal Plants: Their Use in Anticancer Treatment. Int J Pharm Sci Res. 2015 October 1; 6(10): 4103-4112.

International Agency for Research on Cancer. (2018). latest global cancer data: Cancer burden rises to 18.1 million new cases and 9.6 million cancer deaths in 2018.Available online http://www.iarc.fr/en/mediacentre/pr/2018/pdfs/pr263_E.pdf.

Retrieved 2018.09.24.

Ioannis, R.P, Anastasis, $S$ and Andreas $Y$ (2015). Graviola: A Systematic Review on Its Anticancer Properties. American Journal of Cancer Prevention, 3(6), 128131.

Moghadamtousi, SZ, Kadir, HA, Paydar, M, Rouhollahi, E, Karimian, H (2014) Annona muricata leaves induced apoptosis in A549 cells through mitochondrialmediated pathway and involvement of NF$\kappa B$. BMC Complement. Altern. Med. 14:299.

Pai, BM, Rajesh, G, Shenoy, R, Rao, A (2016) Anti-microbial Efficacy of Soursop Leaf Extract (Annona muricata) on Oral Pathogens: An In-vitro Study. Journal of Clinical and Diagnostic Research: JCDR. 10(11): ZC01-ZC04.

Pieme, C, Kumar, S, Dongmo, M, Moukette, B, Boyoum, F., Ngogang, J, Saxena, A. (2014) Antiproliferative activity and induction of apoptosis by Annona muricata (Annonaceae) extract on human cancer cells. BMC complementary and alternative medicine, 14, 516.

Poorkiani, M, Hazrati, M, Abbaszadeh, A, Jafari, P, Sadeghi, M, Dejbakhsh, T, Panah P.M. (2010) Does a rehabilitation program improve quality of life in breast cancer patients. Payesh. 9(1):61-68.

Repetto, G, Del Peso A, Zurita, JL (2008). Neutral red uptake assay for the estimation of cell viability/cytotoxicity. Nat Protoc 3: 1125-1131. Nature protocols. 3. 1125-31. 10.1038/nprot.75. 
Reuben, SC, Gopalan, A, Petit, DM, Bishayee, A. (2012) Modulation of angiogenesis by dietary phytoconstituents in the prevention and intervention of breast cancer. Mol Nutr Food Res. 56(1):14-29.

Roche (2016) "Breast cancer A guide for journalists on breast cancer and its treatment," Roche, pp. 3-6,

Syed Najmuddin, SU, Romli, MF, Hamid, M, Alitheen, NB, Nik Abd Rahman NM. (2016) Anti-cancer effect of Annona muricata Linn Leaves Crude Extract (AMCE) on breast cancer cell line. BMC Complement Altern Med. 16(1):311.

Torres, M, Rachagani, S, Purohit, V, Pandey, P, Joshi, S, Moore, E, Batra, S
(2012) Graviola: a novel promising natural-derived drug that inhibits tumorigenicity and metastasis of pancreatic cancer cells in vitro and in vivo through altering cell metabolism. Cancer letters, 323(1), 29-40.

Zamudio-Cuevas, Y, Díaz-Sobac, R, Vázquez-Luna, A, Landa-Solís, C, CruzRamos, M, Santamaría-Olmedo, M, Martínez-Flores, K, Fuentes-Gómez, AJ, López-Reyes, A (2014) The antioxidant activity of soursop decreases the expression of a member of the NADPH oxidase family. Food Funct. 5(2):303-9. 